PRZEGLĄD RUSYCYSTYCZNY 2020, nr 4(172)

DOI $10.31261 /$ pr. 9100

BOŻENA ŻEJMO

Uniwersytet Mikołaja Kopernika w Toruniu

(D) ORCID: https://orcid.org/oooo-0002-2850-6308

\title{
ПОСТЧЕРНОБЫЛЬСКОЕ ИСКУССТВО КАК РАБОТА ГОРЯ
}

POST-CHERNOBYL ART AS A WORK OF THE MOURNING

The objective of the paper is to give an overview of and to analyse the Post-Chernobyl Art, which not only is perceived as an artistic comment on the Chernobyl tragedy but, most of all, as a way of working through the social trauma. The Post-Chernobyl Art is a remarkable panorama of the post-apocalyptic culture (both high and low) oriented toward a reflection on what happened; it is also a story about victims of the tragedy and a warning to the future generations.

Keywords: Chernobyl, catastrophe, art, apokalipsa, trauma

26 апреля 2020 года исполнилось 34 года с того момента, как старинное славянское слово «чернобыль» перестало ассоциироваться лишь с названием сорной травы и древним городком в украинском Полесье. Теперь оно невольно отождествляется с образом аварии (и её последствий) на самой известной в мире атомной станции и началом новой эры в истории человечества. Постчернобыльской эпохе, как и любой другой, свойственны новые идеи, мышление, антропология. Как сказал украинский художник Алексей Бреус: «Чернобыль - это не только чудовище, порожденное сном разума, это еще и грандиозное произведение искусства, включающее в себе разнообразие форм, сюжетов, идей» ${ }^{1}$. Постчернобыльское искусство - необыкновенная

1 А. Бреус, Чернобыль - это не только «чудовище, порожденное сном разума», это еще и грандиозное произведение искусства!, бесед. А. Лобановская, http://pripyat.com/literature-and-art/khudozhnik-aleksei-breus-chernobyl-etone-tolko-chudovishche-porozhdennoe-snom-ra (02.02.2018). 
панорама посткатастрофической культуры, предлагающая опыт рефлексии, осмысления и осознания случившегося. Это рассказ о горе по жертвам, о культурных механизмах памяти и скорби, а также предостережение будущим поколениям. «Работа горя» - замечает Александр Эткинд - «возвращает мертвых к жизни», «репрезентация прошлого делает его настоящим» ${ }^{2}$.

Постчернобыльское искусство как практика переработки травмы вызывает вопрос о (не)возможности изображения травматических событий:

Чернобыль - травма многоуровневая: личная, общественная, природная, и даже планетарного масштаба [...]. Поэтому необходима не только сильная философская закалка, чтобы её осмыслить, но и помощь от нефилософских взглядов на мир, например от искусства. Думая о Чернобыле, пытаясь осмыслить Чернобыль, мы подходим к границам возможностей человеческой мысли. Не только чувства перестают работать, но и мысли подходят к своему пределуз.

Французский мыслитель Эммануэль Левинас, говоря о воссоздании травматических ситуаций, «предложил, чтобы их рассматривать как 'репрезентации в кавычках'»4. Украинская исследовательница Тамара Гундорова, ссылаясь на концепцию «непредставимого 5 Жана Франсуа Лиотара, считает, что «говорить об атомной вспышке как о реальности невозможно: ведь речь идет о полном разрушении мира, единицы и само-

2 А. Эткинд, Кривое горе. Память о непогребенньх, Новое Литературное Обозрение, Москва 2016, с. 11.

3 М. Мардер, Философская антропология, современные медиа и философия растений, бесед. А. Доронина, В. Башков, А. Бреус, Высшая школа экономики 20.07.2018, https://www.hse.ru/ma/philosophical/news/221806466.html (02.09.2018). Французский философ Поль Вирилио о чернобыльской катастрофе говорит: «[...] мы имеем дело с тремя катастрофами в одной, с некой катастрофой-триптихом: катастрофой субстанции [...], катастрофой знания [...] и, наконец, катастрофой сознания [...]». П. Вирилио, С. Алексиевич [беседа], Радиоактивный огонь. Почему опыт Чернобыля ставит под сомнение нашу картину мира, «Lettre International» 2003, № 1 (60), c. 11-15, http://alexievich.info/wp-content/uploads/articlesDialog.pdf (02.04.2018).

4 По: T. Hundorowa, Gatunek czarnobylski: wyparcie realnego i nuklearna sublimacja, przeł. P. Tomanek // Po Czarnobylu. Miejsce katastrofy $w$ dyskursie współczesnej humanistyki, red. I. Boruszkowska, K. Glinianowicz, A. Grzemska, P. Krupa, Wydawnictwo Uniwersytetu Jagiellońskiego, Kraków 2017, с. 57. Если не обозначено иначе, все переводы мои - Б. Ж.

5 Ср. Ж.-Ф. Лиотар, Ответ на вопрос: что такое постмодерн?, пер. А. Гараджи // Ad Marginem'93, Ad Marginem, Москва 1994, с. 317. 
го языка» ${ }^{6}$. Так как «Чернобыль стал местом невыразимого в культуре, подобно Освенциму, Хиросиме, Холокосту», ученая вводит понятие «безъязыкости»7. Добавляет, однако, что фигуративное мышление ориентируется на то, чтобы всё-таки изобразить невыразимое, невысказываемое, «восстановить объект» ${ }^{8}$. Следуя этой позиции, мы попытаемся доказать, насколько т. н. высокая культура - прежде всего живопись с её языком символов и метафор - способна играть роль свидетеля катастрофы и проработать её в культурной памяти 9 .

\section{ДЕКОРАТИВНОЕ ИСКУССТВО - ГОБЕЛЕН ЧЕРНОБЫЛЬ}

Александр Кищенко (1933-1997), белорусский живописец, художник-монументалист, автор многих росписей и панно, является также одним из основателей школы белорусского современного гобелена. Вершиной его творчества стали две взаимосвязанные работы: Чернобыль (1991, размер 10х4м) и, внесенный в Книгу рекордов Гиннесса, самый большой гобелен мира Гобелен века (1996, размер 19х14м). Первое произведение, подаренное самым Кищенко, находится в здании Организации Объединённых Наций в Нью-Йорке. На торжественной церемо-

6 T. Hundorowa, Gatunek czarnobylski..., c. 58.

7 Т. Гундорова, Пост-Чернобыль: катастрофизм и нуклеарная сублимация, «Русская антропологическая школа. Труды» 2012, вып. 11, с. 114-115.

8 T. Hundorowa, Gatunek czarnobylski..., c. 59. Ср. также высказывания украинской писательницы Оксаны Забужко о ее двадцатипятилетнем опыте молчания по поводу Чернобыля. O. Zabużko, Planeta Piołun - Dowżenko - Tarkowski - von Trier albo dyskurs nowej grozy, przeł. K. Kotyńska // Po Czarnobylu..., c. 38-39.

9 Вне моего исследования остается роль поп-культуры в общественной памяти. Как констатирует Томаш Маевски, массовая культура: «имеет своеобразный характер. [...] она не является против-памятью, против-повествованием по отношению к какой-то существующей, мощной форме репрезентации. Это скорее всего тип символической пустоты, в которой существует апокалиптический язык, который может бытьпроработан на много способов». Humanistyka trzydzieści lat po Czarnobylu. Dyskusja panelowa; uczestnicy: T. Hundorowa, I. Iwasiów, T. Majewski; prowadzenie: A. Grzemska // Po Czarnobylu..., c. 376. Cp. также интересное замечание Бартоша Шурика об Апокалипсисе в массовой культуре: «Целью большинства апокалиптических произведений не является никакое поучение. Все они должны быть привлекательны для потребителя, поскольку в самом мотиве угрозы заложено что-то естественно восхитительное, так же, как и в силе мощной разрушительной стихии заключается эстетическая красота». B. Szurik, A-pop-kalipsa, „Znak” 2013, nr 692, c. 122. 
нии передачи гобелена художник о своём полотне-предостережении сказал, что это - «глаза Беларуси и её боль. [...] в XX веке атом превратился в Дракона, которого надо остановить» ${ }^{10}$.

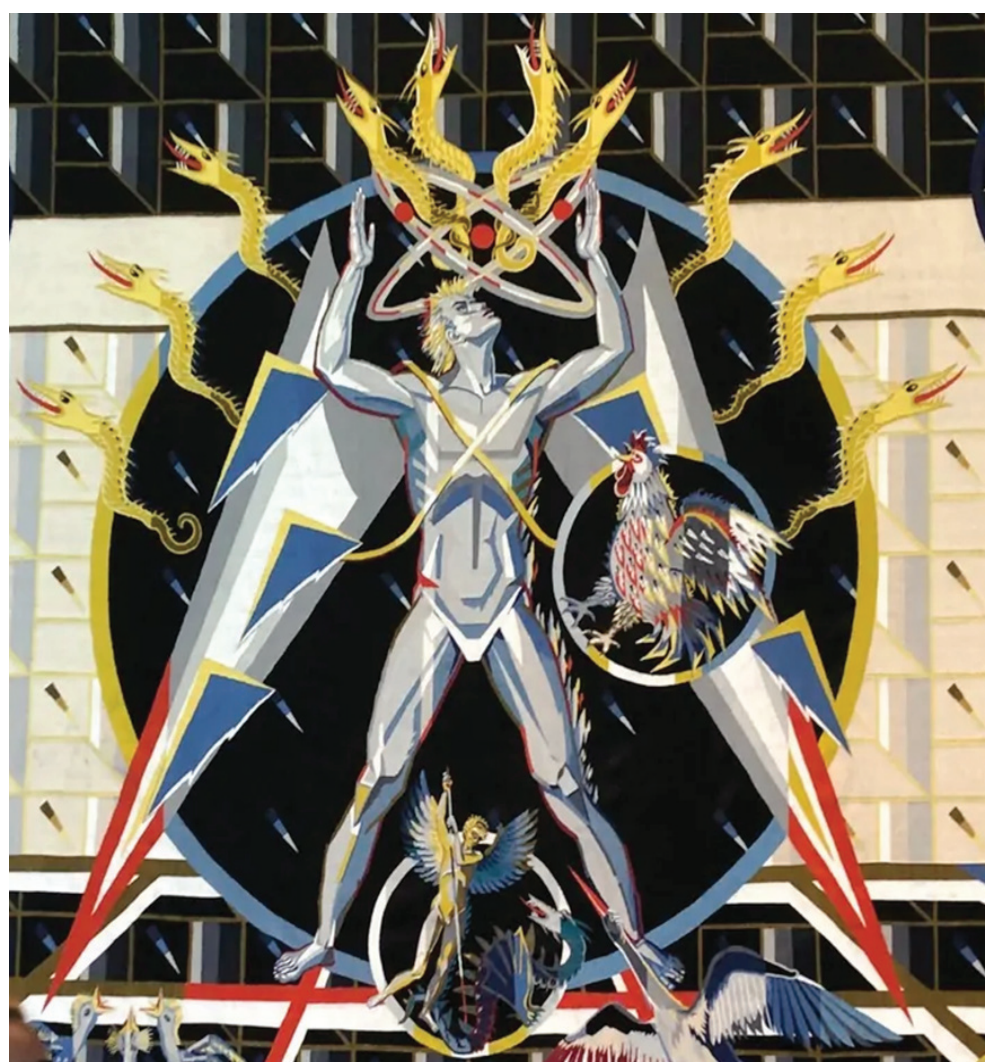

Ил. 1. Александр Кищенко, Чернобыль (гобелен, фрагмент)

(https://www.passblue.com/wp-content/uploads/2019/o9/ChernobylA.jpg)

Согласно «законам декоративного искусства, художник не изображает ужасов чернобыльской трагедии, а лишь ассоциативно - цветовыми контрастами, противоборством круглых и острых плоскостей - вызывает чувство беспокойства, опасности», предостерегает перед пагубными последствиями техногенной катастрофы ${ }^{11}$. Искусствовед Лариса Финкельштейн, декодируя символику гобелена, пишет:

${ }^{10}$ И. Абросимский, Жил-был художник... (Творческий путь Александра Кищенко), «Подъём» 2013, № 8, с. 130.

11 Л. Финкельштейн, Гобелен «Чернобыль»-дар Беларуси ООН, https://www. un.org/ru/events/chernobyl/gobelen.shtml (24.09.2018). 
В больших и малых кругах, словно в клеймах икон, возникают фрагменты «жития» Земли белорусской от древности до наших дней. Трехчастность композиции восходит к иконе складеню. В прошлом - истоки национальной культуры: [...] девочка со свечой - знаком вечной жизни души. В настоящем - катастрофа, о которой прокричал петух. Неукротимый огонь вырвался из круга и рук человека. Языки его - змеи - словно волосы богини мщения Эриннии, Георгий Победоносец с древней иконы убивает змея копьем, а белорусский мальчик молит небо о милосердии к нерожденным жизням, которых не принесет сожженный аист. Словно с герба XVI века сошла Минская дева Мария, покровительница города, чтобы вновь охранить его от беды ${ }^{12}$.

Будущее, надежду на жизнь, символизируют: «жертвенная и вечная как языческое солнышко рядом» Мадонна с младенцем, а также «чаша со щедрыми дарами земли». Вся композиция опирается на напряжение и, одновременно, равновесие между трагедией и надеждой - толкует смысл гобелена белорусский искусствовед. Серафимы-архангелы - вещают не благо, а горе;

кресты, словно надгробия; нестерпима боль земли [...]. Но крест - и модель мира; и окна в него - осколки космоса, и птицы - живая жизнь. В статику вертикальных, словно окаменевших от ужаса фигур, врывается диагональ летящих мадонн, рождая иллюзию объема ${ }^{13}$.

Противостояние сил жизни и смерти отражается также в цветовой гамме гобелена: «черные плоскости смерти, желтые всполохи тревоги усмиряются, едва различимыми искрами красного» (символ животворной крови) и «доминантой белого как символа «рождения новой жизни». Таким образом, констатирует Лариса Финкельштейн, «в монументальной текстильной картине [...], мастерски вытканной, предстал своеобразный портрет Беларуси, с ее богатой историей, современной трагедией и великой надеждой ${ }^{14}$.

Гобелен века, на котором переплетаются библейские сюжеты (Ноев Ковчег), фигуры выдающихся писателей (Эрнест Хемингуэй) и политиков (Владимир Ленин, Уинстон Черчилль, Михаил Горбачев, Александр Лукашенко), можно воспринимать как своеобразное продолжение темы Чернобыля. Как констатировал Кищенко:

[...] я решил показать мятущийся уходящий XX век. Гобелен века - это как бы завершение многих, ранее поднятых [мною - Б. Ж.] тем. Что в нём

12 Здесь и дальше анализ символики гобелена по: там же.

${ }_{13}$ Там же.

14 Там же 
конкретно? В центре - тайная вечеря. Христос и Антихрист. Христос защищает свою правду и веру. На мече Антихриста слова: «Побеждает сильный». Христос останавливает меч, как бы говоря: «Побеждает вера в добро». В этом главный смысл картины ${ }^{15}$.

\section{ИНСТАЛЛЯЦИЯ ВАННА-КОЛЫБЕЛЬ}

Автором художественной работы, где на фоне чернобыльской трагедии ставится вопрос украинской идентичности, является украинско-канадский художник Тарас Полатайко. Инсталляция Колыбель (1995) - это ванна, которая подобно детской колыбели подвешена к потолку на якорных цепях, а сверху закрыта металлическим листом с небольшим окошком ${ }^{16}$. Этот «маленький глазок, как в дверях» - объясняет в своей лекции критик и менеджер культурных проектов Катерина Ботанова -

[...] единственное место, куда вы можете посмотреть, чтобы увидеть, что внутри. Но сверху бьет луч света, который, отражаясь от металлической поверхности, ослепляет смотрящего, и вы ничего не видите. Такой очень нежный, очень художественный, очень болезненный проект, с помощью которого Тарас рассказывает нам о том, кто мы есть, кем мы можем быть и что с этим всем делать ${ }^{17}$.

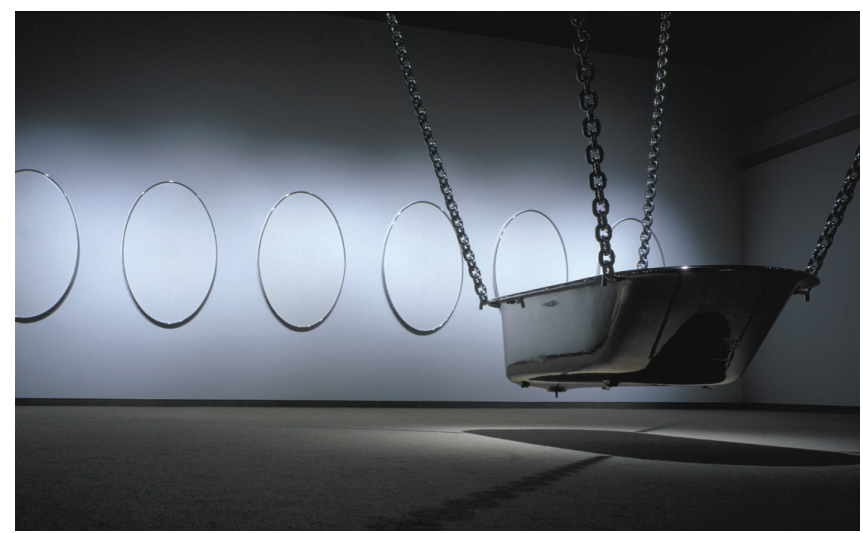

Ил. 2. Тарас Полатайко, Колыбель (инсталляция) (www.100artists.com.ua/paint/2500.html)

15 По: И. Абросимский, Жил-был художник..., с. 131.

${ }^{16}$ Впервые показана в канадской галерее Мендель, в Украине никогда не выставлялась.

${ }^{17}$ К. Ботанова, C чем работает современное искусство? Украинский контекст, 15.03.2013, http://eurocafe.by/lecture/2013/o8/21/s_chem_rabotaet_ sovremennoe_iskusstvo_ukrainskii_kontekst (15.08.2018). 
Внутри ванны находятся пять литров крови художника, которую он собрал после своей поездки в Чернобыль в начале 1990-х годов. О своём творческом замысле Полатайко говорил:

Была идея поехать в Чернобыль, пожить там месяц, подышать воздухом, не для того, чтобы умереть, а получить дозу вредных элементов. Затем в Канаде полностью сделать рециркуляцию крови. Кровь сдавал год. Заполнил ней ванну ${ }^{18}$.

Это не только символический жест возвращения на родину, но также «попадания в ту самую болезненную точку родины, самую опасную, самую кровоточащую, самую страшную» ${ }^{19}$.

Если рассматривать конструкцию Полатайко сквозь призму славянской культуры и традиции, колыбель - это «первая земная обитель человека, объект и локус магических оберегов, направленных на защиту жизни и здоровья ребенка; в своем символическом значении соотносится с материнской утробой» ${ }^{20}$. Всех этих качеств жизнедеятельности лишена чернобыльская колыбель, заполненная отравленной кровью. Настроение губительности и разрушения подчеркивается и другими признаками ванны-колыбели. Во-первых - ее неподвижность. Если качание в колыбели стимулирует рост и развитие ребенка, то находящаяся в застывшем положении чернобыльская колыбель делает невозможным всякое изменение, подъем, процветание, стремление к лучшему. Неслучайно Полатайко подобрал также в качестве материала металл, в то время как колыбели традиционно делались из разных пород деревьев, прежде всего быстрорастущих (верба, орех), «чтобы ребенок хорошо рос», или долговечных (как боярышник), «чтобы он долго жил» ${ }^{21}$. Быстрому росту дерева, его прочности и стойкости противопоставлен обработанный металл с химической реакционной способностью корродировать. Образуется пара полярных противоположностей, одна из самых главных мифологических оппозиций: верх (то, что

${ }^{18}$ А. Балакир, Художник Тарас Полатайко сдал 5 литров крови для инсталляции, 16.07.2012, https:/gazeta.ua/ru/articles/culture/_hudozhnik-taraspolatajko-sdal-5-litrov-krovi-dlya-installyacii/445931 (23.08.2018).

${ }_{19}$ К. Ботанова, С чем работает современное искусство? Украинский контекст...

${ }^{20}$ С. М. Толстая, Кольбель // Славянские древности. Этнолингвистический словарь, под ред. Н. И. Толстого, т. 2, Институт славяноведения РАН - Международные отношения, Москва 1999, с. 559.

${ }^{21}$ Там же. 
космическое, природное, изначальное, вечное) - низ (созданное человеком, временное). Соответственно, дерево относится к вертикальному порядку, металл - к горизонтальному. Таким образом чернобыльская ванна-колыбель указывает на опасное перемещение между мирами, неизбежно приводящее к гибели.

Эффект апокалипсиса реализуется также в символике цвета крови - красный может ассоциироваться не только со смертью и страданием, но также со стыдом и бесчестием ${ }^{22}$. По словам Марка Твена «человек - это единственное существо, которое краснеет или по крайней мере должно краснеть»²3. Следуя остроумному замечанию американского писателя, можно предположить, что своей инсталляцией Полатайко пытается опозорить, дискредитировать советскую власть, которая должна «покраснеть» от стыда за Чернобыль.

\section{ТРАГЕДИЯ НА ХОЛСТЕ}

Значимое место в постчернобыльском искусстве принадлежит живописи. Катастрофа нашла художественное воплощение в произведениях представителей разных поколений и стилевых направлений: от традиционно реалистического (Михаил Савицкий, Виктор Шматов, Владимир Гордеенко), до эмоциональноассоциативного с использованием современного пластического языка (Алексей Марочкин, Николай Селещук, Владимир Кожух).

Особого внимания заслуживает творчество белорусского живописца Михаила Савицкого (1922-2010). Над темой Чернобыля художник начал работать почти сразу после взрыва и продолжал её на протяжении десятилетия. Его картины - «свидетельство умения мыслить образами философского, масштабного характера ${ }^{24}$ - отличаются психологизмом и эмоциональностью, а также ярко выраженной моральной позицией их автора:

Душевное состояние человека в его работах 1990-х годов не подается как движение, в развитии, а подчеркивается его застылость, закрытость. [...] Каждая из композиций держится на одной трагической ноте безысход-

${ }^{22}$ См. Д. Фоли, Энциклопедия знаков и символов, перев. А. Помогайбо, Вече, Москва 1997, с. 427-430.

${ }^{23}$ По: там же, с. 430.

${ }^{24}$ В. И. Жук, Живопись Беларуси на рубеже веков: потери и обретения, Беларуская навука, Минск 2013, с. 18. 
ности [...], безнадежной покорности [...] перед бедой. [...] беззащитности [...] в сложившихся обстоятельствах [...]. Для него [Савицкого - Б.Ж.] не характерно цветовое воплощение жизни, декоративность и многословность живописного высказывания. Главная особенность его картин - их внутренняя напряженность, где прячется гуманистическая повесть о духовной силе человека в самих экстремальных обстоятельствах 25.

Свой цикл художник назвал Чёрная быль, подчёркивая заглавием правду изображенных событий. Серия состоит из 11 картин: Эвакуация, Зрячий, Плач о земле, Крест надежды, Покинутые, Доля, Реквием, Чернобыльская мадонна, Запретная зона, Ностальгия, Аллегория Чернобыля. Плач о земле вписывается в существующую с глубокой древности плачевую традицию. Плачи и причитания (жанр обрядового фольклора) исполнялись плакальщицами, специально приглашаемыми для оплакивания умершего родственника или выражения горя по поводу разных стихийных бедствий. На картине Савицкого плакальщики скорбят о родной белорусской земле в момент постигшего её трагического испытания. Чувство боли и глубокого страдания подчеркивается мрачной траурной атрибутикой: чёрная краска, поглощающая весь изображенный мир. Инерционное движение изображенных фигур и отсутствие ярких красок свидетельствуют о смерти всяких форм жизни. Сплошная темнота соответствует состоянию убитых горем: образ молящихся, стоящих на коленях, взирающих в небо людей вполне отвечает эмоциональному настрою похоронных причитаний. Черное пятно на фоне образует дыру в небе, бездну, пустоту. В космогонических представлениях пустота понимается как Чистое Ничто (Мировая Бездна, Мировая Тьма) - нежизнеспособное, пассивное, абсолютный хаос и беспорядок, неразличимый мрак (безвидность), абсолютное незнание ${ }^{26}$. В мифологии славян (и не только) пустота как отсутствие блага всегда выступает в оппозиции к полноте (наполненности), воплощающей собой жизнь ${ }^{27}$. Само слово происходит от

${ }^{25}$ Там же, с. $16,18$.

${ }^{26}$ См. В. Н. Топоров, Мифология. Статьи для мифологических энциклопедий, предисл. Вяч. Вс. Иванова, ред.-сост. А. Григорян, т. 1, Языки славянских культур, Москва 2011, с. 313 [Космос]; Его же, Мифология. Статьи..., т. 2, Москва 2014, с. 422 [Хаос]; Д. А. Гаврилов, НордХейм. Курс сравнительной мифологии древних германцев и славян, Социально-политическая МЫСЛЬ, Москва 2006, с. 23.

${ }_{27}$ См. А. А. Плотникова, Полный-Пустой // Славянские древности..., т. 4, Москва 2009, с. 145-146. 
праслав. pustъ (пустой) - «не заполненный [...] в соответствии со своим назначением ${ }^{28}$. Пустое место в небе на картине Савицкого генерирует смысловую цепочку: если небо - это место Бога, то после Чернобыля Его там больше нет.

Чернобыль - трагический пример, укор и урок миру; человек своей гордыней разрушает вселенскую гармонию и жестоко расплачивается за это. Эта мысль расширяет тему Чернобыля, обретая космический масштаб. Мотив конца света особенно активен в украинской постчернобыльской живописи, воплощаясь в сложной образной системе символов. Критик Мария Хрущак отмечает, что после Чернобыля украинское искусство «с головой ушло в мистику, оставшись при этом искусством живописным и изобразительным» ${ }^{29}$. В 1994 году Юрий Никитин, последовательно адаптирующий традицию украинского барокко к современности, создал отчаявшуюся Чернобыльскую Богоматерь. «Безумный страх перед будущим и возможными „деформациями" форм живого» ${ }^{0}$ породил такие визионерские проекты, как Сакральный пейзаж Питера Брейгеля Георгия Сенченко или Современная Помпея и Чернобыльские призраки Сергея Давидовича (р. 1942).

Чернобыльские призраки, последняя из названных картин, изображает скелет человека-дерева с протянутыми в сторону неба руками-ветвями. Весьма показателен факт, что чернобыльский человек-дерево лишен внутренних органов, вместо которых зияет пустота. Все части его тела иссохшие, худые, костлявые. Акт очевидной смерти сопровождается криком отчаяния, на что указывает отверстие в верхней части дерева, напоминающее широко раскрытый человеческий рот. Могущество этого всеобъемлющего болезненного крика усиливает многократный повтор образа таких же умирающих и кричащих от боли деревьев.

Образ может вызывать различные ассоциации, в зависимости от того, на каком семантическом плане фокусируем свое внимание. Некоторые аналогии появляются уже на визуальном уровне, который в свою очередь ведет к более глубокому идей ному смыслу. На нескольких иллюстрациях Уильяма Блейка

${ }^{28}$ Большой толковый словарь русского языка, ред. С.А. Кузнецов, «Норинт», Санкт-Петербург 2006, с. 1047 [Пустой].

29 По: К. Дорошенко, Конец света. Искусство Чернобыля, 21.12.2012, https:// artguide.com/posts/277-koniets-svieta-iskusstvo-chiernobylia-307 (23.05.2018).

${ }^{30}$ Там же. 


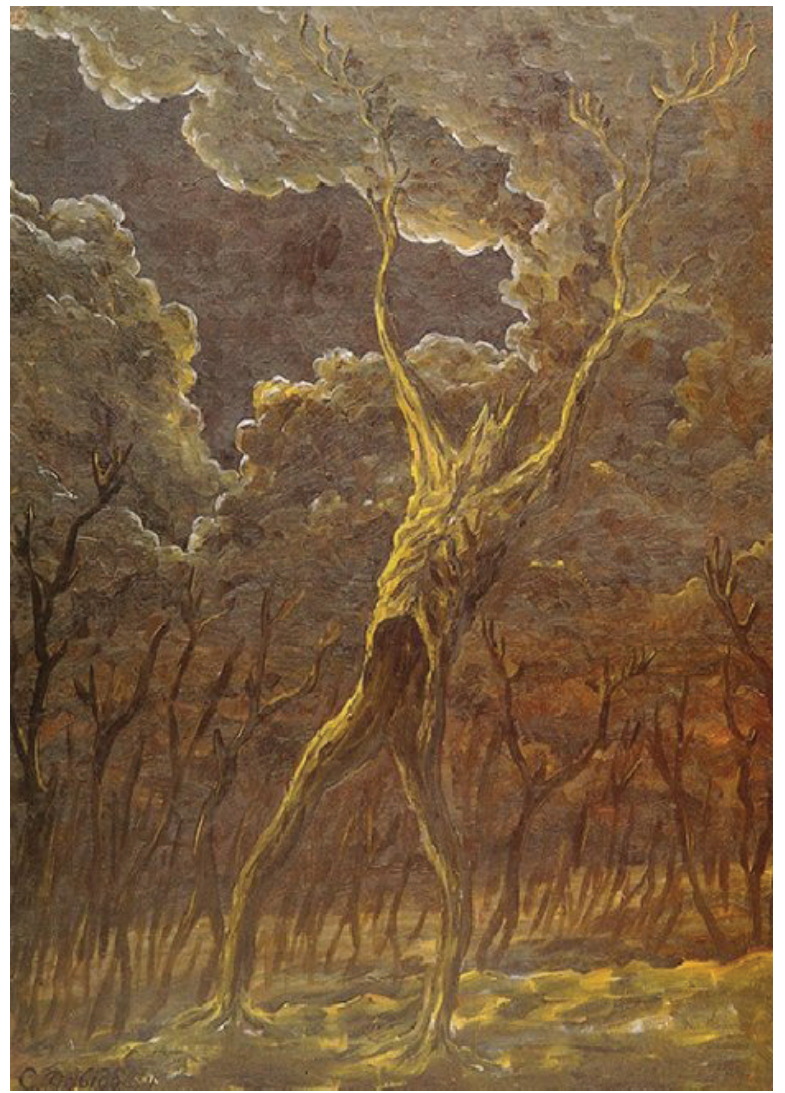

Ил. 3. Сергей Давидович, Чернобыльские призраки (https://ecoidea.by/ru/article/1363)

к песням Божественной комедии Данте, описывающим круги Ада (I, II,VII), повторяется лес мрачных, зловещих деревьев. В круге VII (2-й пояс) страдают насильники, в том числе самоубийцы. Не таким же наказанным насильником (не только над самим собой, но и над всем человечеством) является изображенный на картине Давидовича человек-дерево, если посмотреть на трагедию Чернобыля как на результат варварской человеческой деятельности, насилующей природу? Человек сам себя погубил. Лес страдающих, испытывающих адские муки людей-деревьев, отсутствие теплых, ярких красок, тяжелые, буревые тучи (на картине Давидовича) - весь набор этих признаков указывает на место греховных заблуждений, где карается злоба, орудующая всякой силой (насилием). 
Возможна и другая гомотипия. Изображенная Давидовичем фигура кричащего от ужаса и боли скелета явно отсылает к картине Крик норвежского художника- экспрессиониста Эдварда Мунка. Сходные точки заметны уже с первого взгляда. Эффект раздающегося повсюду крика передается особым повтором: широко раскрытый рот - волнообразные контуры головы - закруглённые линии пейзажа. Деформации подвергается человек и вся природа, сужается перспектива, мир погружается в хаос. Негативные эмоции человека-призрака подчиняют себе окружающий мир, приобретая вселенский размах. Крик агонизирующего человека переплетается с раздающимся отовсюду криком природы. В литературе высказываются разные версии обстоятельств создания Крика. Одна из них относится к кровавым закатам - следствие извержения вулкана Кракатау в 1883 году - поразившим воображение художника необыкновенным зрелищем. В своём дневнике художник писал:

Я шёл по тропинке [...] солнце садилось - неожиданно небо стало кроваво-красным, я приостановился, чувствуя изнеможение, и опёрся о забор - я смотрел на кровь и языки пламени над синевато-чёрным фьордом и городом [...] я стоял, дрожа от волнения, ощущая бесконечный крик, пронзающий природу ${ }^{31}$.

Оба художника затрагивают вопрос о роли и месте человека в природном универсуме. Однако, если Мунк предвещал своим Криком различные катастрофы XX века, Давидович изобразил катастрофу уже сбывшуюся.

Наконец обратимся к прочтению картины Давидовича как мифопоэтической системы. Все изображенное пространство заполняет лес, которому нет предела, что создает впечатление отсутствия какого-нибудь другого мира. Сам образ темного, густого леса в славянской мифологии и фольклоре - это опасный локус, «наделенный признаками удаленности, непроходимости, необъятности, сближаемый с «тем светом»; место чуждое всему человеческому ${ }^{32}$. С представлением иномирности и удаленности леса связаны фигуры демонические: черти, мары, злые духи, призраки. Лес - это также «нехватка духовного видения и света, человечество потерянное во тьме, в гордыни, не направлен-

${ }^{31}$ А. Чудова, Эдвард Мунк, Издательство АСТ, Москва 2018, с. 38.

$3^{22}$ См. Т.А. Агапкина, Лес // Славянские древности..., т. 3, Москва 2004, с. 97. 
ное Богом»33. На картине Чернобыльские призраки среди стволов не мелькает даже малейшего света, что можно толковать как окончательную потерю какой-либо надежды на обретение места защиты от смерти ${ }^{34}$, возвращение «к доисторическому мраку неизвестности», неосвоенное пространство, открывающее «доступ в мир Хаоса и Смерти» ${ }^{35}$. Семантическое поле леса не исчерпывается признаками враждебности и опасности, лес наделен и противоположной символикой - это женское начало: Мать Земля, плодовитость, материнство ${ }^{36}$. Лес (как и пещера) - первое жилище человека, «его первый дом» ${ }^{37}$. В этом контексте лес Давидовича представляется как разрушение того, что первичное, святое, что заложенное в самом Начале Жизни; это разрыв жизненного цикла. Так как Начало маркирует главным образом дальнейшее существование во времени, развитие, возрастание ${ }^{38}$, то чернобыльская трагедия - скачок в мир призраков, в небытие, в космический Конец. Образ апокалиптического разрушения подтверждается и одновременно усиливается еще одной мифологической константой: отождествлением человека и дерева. Жизнь (также смерть) обоих существ взаимообусловлена, они становятся единством. Поскольку «дерево корнями уходит в землю, а его ветви устремлены к небу, оно, как и сам человек, является отражением сущности двух миров»39. Давидович символически обыгрывает антропоморфность дерева: ветви дерева - руки, корни - стопы. Решающим является тут факт, что во многих древних культурах дерево рассматривается и «как ось мира, вокруг которой группируется космос» ${ }^{40}$. Засохшее чернобыльское дерево-человек символизирует нарушение космической гармонии.

Апокалиптическая символика использована Давидовичем непосредственно и в картине Зрячий, на что указывает надпись

33 Дж. Купер, Энциклопедия символов, Золотой Век, Москва 1995, с. 178.

${ }^{34}$ Ср. Г. Бидерманн, Энциклопедия символов, пер. В. Вальков и др., Республика, Москва 1996, с. 147.

35 С. Д. Домников, Мать-земля и Царь-город. Россия как традиционное общество, Алетейа, Москва 2002, с. 68, 76.

${ }^{36}$ W. Kopaliński, Stownik symboli, Oficyna wydawnicza RYTM, Warszawa 2001, c. 186.

37 Там же.

${ }^{38}$ См. М.М. Валенцова, Е.С. Узенёва, Начало-Конец // Славянские древности..., т. 3, с. 374.

${ }^{39}$ Г. Бидерманн, Энциклопедия символов..., с. 69.

40 Там же. 
в верхней части - фрагмент из пророчества Снятия пятой печати Откровения Иоанна Богослова: «И сказано им чтобы они успокоились» ${ }^{41}$.

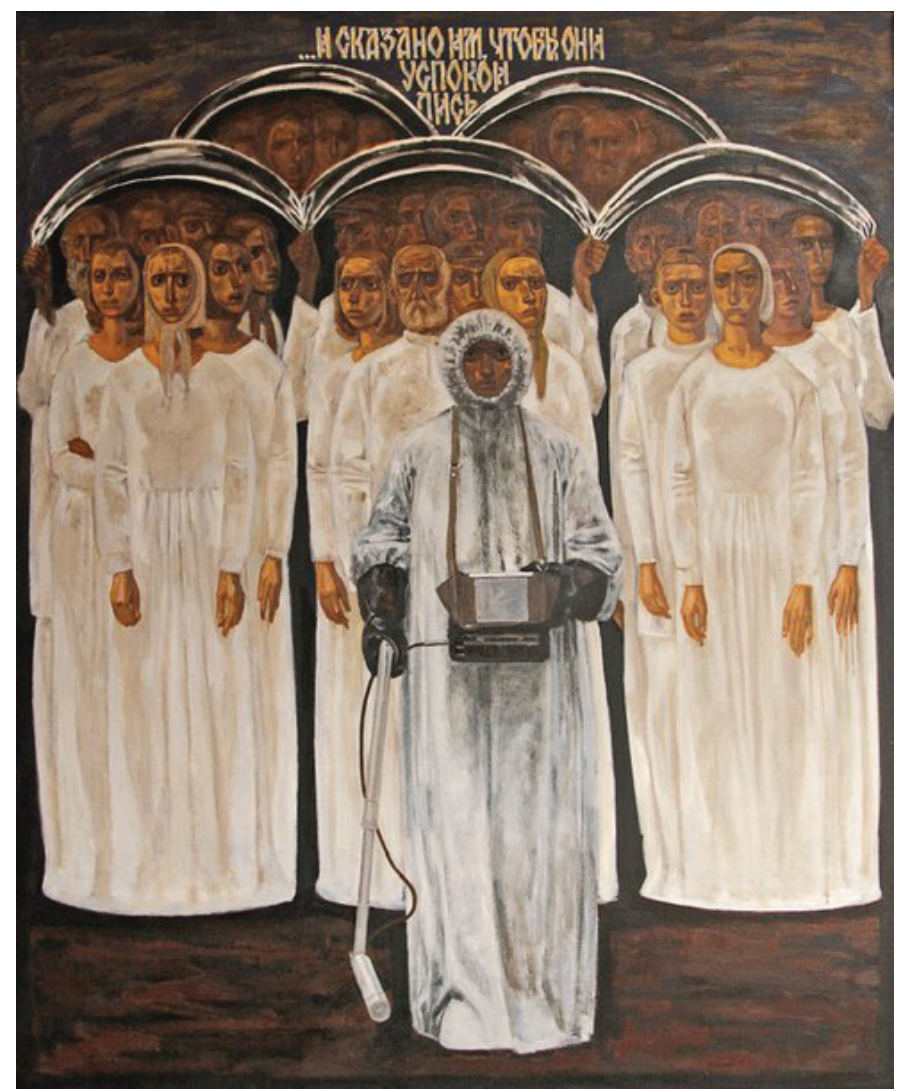

Ил. 4. Сергей Давидович, Зрячий (https://ecoidea.by/ru/article/1363)

Протоиерей Александр Мень комментирует пророчество следующим образом:

Вопль крови - это древний образ. Уже в Книге Бытия, когда Авель был убит Каином, Господь говорит - Кровь вопиет к небу. Значит, в мире есть какой-то таинственный закон, который греки называют законом дикэ, индийцы - законом кармы, а мы называем законом воздаяния. Зло не может остаться неотмщенным, оно обязательно - в том или этом мире - каким-

${ }^{41} \mathrm{Cp}$. «И даны были каждому из них одежды белые, и сказано им, чтобы они успокоились еще на малое время, пока и сотрудники их и братья их, которые будут убиты, как и они, дополнят число» [Откр 6:11]. 
то образом должно уравновеситься [...] Страшный суд нужен, он нужен человеку [...], иначе нет праведности Божьей, нет справедливости, иначе невозможно жить. Человек требует этого в глубине своей души, в которой попрано нечто, и оно не может быть просто снято, а должно быть изжито ${ }^{42}$.

Другой богослов, Александр Лопухин, объясняет:

В ответ на вопль мучеников им дана была каждому белая одежда, как знак их чистоты и невинности. Дарование ее мученикам имеет значение их оправданности, близости к Богу и надежды на полное блаженство, на воскресение из мертвых. Кроме дарования белых одежд, Господь утешает непреложностью Своего суда по Своему Божьему Предопределению [...]. Время этого суда и воздаяния совпадет с тем временем, когда число мучеников достигнет известного, определенного Богом предела. Кровь мучеников будет отомщена $[\ldots]^{43}$.

Отсылка к Библии отражается также в названии картины Зрячий. Когда Иисус объясняет притчу о сеятеле и семенах, произносит следующие слова: «Ваши же блаженны очи, что видят, и уши ваши, что слышат» (Мф 13:16). Разыгрывая мотив зрения, Давидович аллюзивно намекает на слепоту тех, которые долго закрывали глаза на чернобыльскую трагедию, и одновременно противопоставляет им зрячих героев-чернобыльцев, смело смотрящих смерти в глаза. Последние отражены в фигуре мужчины, держащего в руках прибор для измерения радиации.

Память чернобыльцев-мучеников увековечена и в первой техногенной иконе «Чернобыльский Спас» - память о трагедии, почтение к подвигу, призыв $\kappa$ покаянию, написанной православным деятелем Юрием Андреевым с благословения митрополита Киевского Владимира. В верхней части иконы расположились фигуры Богородицы, Христа и Архистратига Михаила, ведущего живых и мертвых людей Чернобыля. Внизу иконы, на переднем плане, изображена Чернобыльская сосна, которая может ассоциироваться с крестом и, одновременно, трезубцем на гербе Украины. С образом сосны обычно связаны представления о вечной жизни, бессмертии. Это дерево используется во время похоронного обряда, так как «считается, что ветки сосны поддерживают и укрепляют душу покойного» 44 . На её фоне - чет-

${ }^{42}$ А. В. Мень, Читая Апокалипсис, Фонд им. Александра Меня, Москва 20оо, c. 70,73 .

43 Толкования на Откр. 6:11, http://bible.optina.ru/new:otkr:o6:11 (26.07.2018).

44 В. Н. Топоров, Мифология. Статьи..., т. 2, с. 349 [Сосна]. 
вертый блок атомной электростанции и город Припять ${ }^{45}$. Слева изображены души погибших чернобыльцев, справа - ликвидаторы последствий аварии: пожарный, работник станции, летчик и медсестра. Изображенное падение звезды Полынь особенно сильно связано с определенной топонимикой. Во-первых, Чернобыльская катастрофа случилась в месте не только с богатейшей религиозной традицией - здесь в одном небольшом селе умещались две православные церкви, четыре синагоги, костел и доминиканский монастырь - но и с богатой традицией ожиданий Конца. Еще во второй половине XVIII века тут обосновались старообрядцы «чернобыльского согласия», бежавшие от гонений Екатерины II. Возглавлял их Илларион Петров, проповедующий скорое воцарение Антихриста и наступление апокалипси$\mathrm{ca}^{46}$. Во-вторых, «чернобыль» - украинское название «полыни», а последняя в виде аллегорического символа горечи красной нитью проходит через все Священное Писание; она встречается во Второзаконии («да не будет между вами корня, произращающего яд и полынь», Втор 29:18), в Притчах Соломоновых («но последствия от нее горьки, как полынь, остры, как меч обоюдоострый», Притч 5:4), книге Иеремии («Я накормлю их, этот народ, полынью, и напою их водою с желчью», Иер 9:15), в Плаче Иеремии («Он пресытил меня горечью, напоил меня полынью», Плач 3:15) и, самое главное, в откровении Иоанна Богослова, Апокалипсисе, ключевом тексте любой христианской эсхатологии: «Третий ангел вострубил, и упала с неба большая звезда, горящая подобно светильнику, и пала на третью часть рек и на источники вод. Имя сей звезде „полынь”; и третья часть вод сделалась полынью, и многие из людей умерли от вод, потому что они стали горьки» (Откр 8:10-11).

Трагедийный и катастрофический типы чернобыльской живописи объединены апелляцией к возвышенному, а «основанный на возвышенном язык владеет» силой, которая способна вызывать глубокие внутренние эмоции как у самих живописцев, так и у зрителей ${ }^{47}$. «Трагедийный дискурс», как констатирует Тамара

45 Если учесть факт, что Припять - это типичный атеистический городок, в котором не была построена ни одна церковь («город без Бога»), то согласно проповедям, Господь должен был наказать это грешное место.

${ }^{46}$ Чернобыльская катастрофа - боль Украины, https://tsdea.archives.gov.ua/ exhibitions_ru/chern/ index_ch.php?page=ch_history1 (22.06.2018).

47 Т. Гундорова, Пост-Чернобыль..., с. 111. 
Гундорова, «обращен к героям и жертвам, но главное» - он направлен к приподнятому, трансцендентному «смыслу бытия» 48 .

\section{ЛИЧНЫЙ АПОКАЛИПСИС}

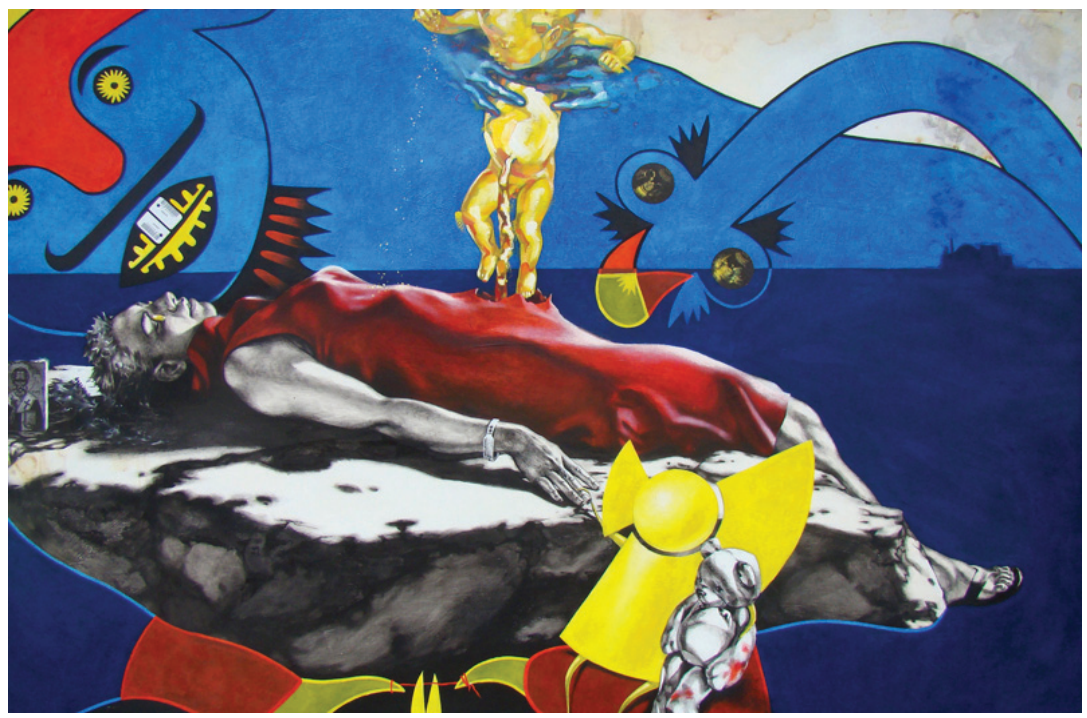

Ил. 5. Кристина Катракис, Омен (проект Зона)

(https://artguide.com/posts/277-koniets-svieta-iskusstvo-chiernobylia-307)

В серии живописных работ, совмещающих академическую живописную школу с увлеченностью сюрреализмом, Кристина Катракис (1980 г.р.) раскрывает интимную историю личного Апокалипсиса - потеря ребенка, родившегося с «чернобыльским» сердцем. Смерть ребёнка воспринимается художницей как прямое последствие облучения - дача, на которой она отдыхала в детстве, оказалась в 3о-километровой зоне реактора. Используя сюрреалистический язык, Катракис пытается достичь глубин своего подсознания, проработать личную травму. Есть и другая цель - альтруистическая:

Тема Чернобыля и онкобольных детей мне очень близка. Моя серия работ Зона выиграла премию ООН. Возможно потому, что она припала людям к сердцу. Ежедневно много детей умирает в Украине и многие рожда-

${ }^{48}$ Там же. 
ются больными из-за этого «монстра», который еще спит. И если мы будем закрывать глаза, то ничего не изменится. Если мы сплотимся, то можем сделать так, чтобы такой трагедии никогда больше не повторилось и вылечить тех детей, которые сейчас страдают от последствий ${ }^{49}$.

Артистка принимает также участие в строительстве клиник для детей: «Сейчас я сотрудничаю с Международным фондом детского сердца. Каждые два месяца известные хирурги приезжают из Америки и оперируют украинских детей с синдромом 'чернобыльского сердца' в Харькове» $5^{\circ}$.

\section{ТРАЛЬФРЕАЛИЗМ - ПРЕОДОЛЕНИЕ АПОКАЛИПСИСА}

В 1990 году в Украине образовалась арт-группа «Стронций-90», объединяющая художников, освещающих чернобыльскую тему в духе т. н. тральфреализма. Несуществующее ни в каком из языков слово «тральф» - это:

[...] фонема - звукоподражание излучению Вселенной в диапазоне, который может услышать человеческое ухо. По крайней мере, так утверждал писатель-фантаст Курт Воннегут, который «обнаружил» во Вселенной планету Тральфамадор. А еще «тральф» - это аббревиатура: «Трансформация Реальности Артом, Любовью, Фантазией» ${ }^{51}$.

Эстетическое и этическое мировоззрение представителей направления цельно суммирует представитель первых тральфреалистов - Алексей Бреус:

[...] предпочитаю не выпячивать чернобыльский негатив, не материализовать его «весомо, грубо, зримо» на холсте. Но он может присутствовать в виртуальной части картины, т. е. в ее идеологии. При таком творческом подходе художник вовсе не забывает о пагубных последствиях Чернобыля и других жизненных невзгодах, но становится как бы фильтром, который не пропускает их к зрителю. [...] Главной эстетической, нравственной и ду-

49 Американка, по фото которой создали Монумент Независимости в Киеве: «Я должна достойно это нести», Сегодня 17.09.2013, https:// www.segodnya.ua/lifestyle/psychology/Amerikanka-po-foto-kotoroy-sozdaliMonument-Nezavisimosti-v-Kieve-YA-dolzhna-dostoyno-eto-nesti--460867. html (02.10.2018).

5о Там же.

${ }^{51}$ Звезда тральфреализма: живые цветы и живые картины, 17.09.2008, http://gloss.ua/event/Zvezda_tralfrealizma_zhivye_cvety_i_zhivye_kartiny (17.12.2018). 


\section{ПОСТЧЕРНОБЫЛЬСКОЕ ИСКУССТВО...}

ховной ценностью тральфреализм безоговорочно признает Гармонию как благотворное созвучие других ценностей [...] Добро, Красота, Любовь, Творчество, Человек. [...] Говоря об экологии мы имеем в виду не только борьбу с загрязнением природы, но и противостояние загрязнению совести, морали, нравственности, в конце концов, душ человеческих. Именно в этой плоскости лежат причины Чернобыля, главная из которых - это дисбаланс между нравственным или духовным уровнем развития общества и теми высокими технологиями, которыми оно пытается овладеть. Без устранения этого дисбаланса человечество обречено на новые катастрофы ${ }^{52}$.

Чернобыльская действительность создала не только катастрофический 53 образ нового мира и нового человека. После Чернобыля предстала сила интуиции больших и маленьких существ утверждают тральфреалисты. Люди более четко осознали свою принадлежность к природе:

Если та трагедия может привести к каким-нибудь положительным выводам, то это будет воля жизни, которая подсказывает, как понять, выжить и приручить мир превращенный в карикатуру. Как победить апокалиптический опыт, как поверить в то, что весь мир (вселенная) наделен мощью восстановления жизни ${ }^{54}$.

Новейшее молодое поколение художников - тем, кому во время чернобыльской катастрофы было мало лет - представляет собой новый тип свидетеля, новый катастрофизм, который, замещая реальное фантазмами, превращает Чернобыль в зрелище ${ }^{55}$.

Подытоживая, можем констатировать, что постчернобыльское искусство не является буквальным восстановлением прошлого, скорее всего, это - попытка зафиксировать место и значение травматического опыта в образах и смыслах, «обозначить следы утраты»56. Участвуя в публичной нарративизации проблемы памяти и травмы, живописец берет на себя роль того, кто помнит. Вопреки скептицизму Светланы Алексиевич («Сколько

$5^{2}$ А. Бреус, Чернобыль - это не только...

53 Особо сильно эта тенденция заметна в литературе, см. Ро Czarnobylu...; Т. Гундорова, Післячорнобильська бібліотека: Украӥнський літературний постмодерн, Критика, Київ 2005.

54 Звезда тральфреализма: живые цветы и живые картины...

${ }_{55}$ См. T. Hundorowa, Gatunek czarnobylski..., c. 60-66.

${ }^{56}$ С. Ушакин, «Нам этой болью дышать»?: О травме, памяти и сообществах // Травма: пункты, ред. С. Ушакин, Е. Трубина, Новое литературное обозрение, Москва 2009, с. 10. 
раз искусство репетировало апокалипсис, предлагало разные технологические версии светопреставления, но теперь мы точно знаем, что жизнь куда фантастичнее» ${ }^{57}$ ), искусство, как лаборатория памяти, наделено мощным потенциалом работы с травмой, а художник способен выполнять роль Вергилия: «И мы получаем возможность разделить опыт современного человека. Художник открывает 'портал’, и возникает возможность понять, что делать дальше» ${ }^{8}$.

\section{REFERENCES}

Abrosimskiy, Ivan. "Zhil-byl khudozhnik... (Tvorcheskiy put' Aleksandra Kishchenko).” Pod"yem 2013, no. 8. 120-134 [Абросимский, Иван. “Жил-был художник... (Творческий путь Александра Кищенко).” Подъём 2013, № 8. 120-134].

Agapkina, Tat'yana Alekseyevna. "Les." Slavyanskiye drevnosti.Etnolingvisticheskiy slovar'. Ed. Tolstoy, Nikita Il'ich. Vol. 3. Moskva: Institut slavyanovedeniya RAN - Mezhdunarodnyye otnosheniya, 2004. 97-100 [Агапкина, Татьяна Алексеевна. “Лес.” Славянские древности. Этнолингвистический словарь. Ред. Толстой, Никита Ильич. Т. 3. Москва: Институт славяноведения РАН Международные отношения, 2004. 97-100].

Aleksiyevich, Svetlana. "Interv'yu avtora s samoy soboy o propushchennoy istorii i o tom, pochemu Chernobyl' stavit pod somneniye nashu kartinu mira." Aleksiyevich, Svetlana. Chernobyl'skaya molitva. Khronika budushchego. Moskva: Vremya, 2013. 30-41 [Алексиевич, Светлана. "Интервью автора с самой собой о пропущенной истории и о том, почему Чернобыль ставит под сомнение нашу картину мира.” Алексиевич, Светлана. Чернобыльская молитва. Хроника будущего. Москва: Время, 2013. 30-41].

"Amerikanka, po foto kotoroy sozdali Monument Nezavisimosti v Kiyeve: 'Ya dolzhna dostoyno eto nesti'.” 17.09.2013 [“Американка, по фото которой создали Монумент Независимости в Киеве: 'Я должна достойно это нести'.” 17.09.2013] <https://www.segodnya.ua/lifestyle/psychology/Amerikanka-pofoto-kotoroy-sozdali-Monument-Nezavisimosti-v-Kieve-YA-dolzhna-dostoynoeto-nesti--460867.html>.

Balakir, Anna. "Khudozhnik Taras Polatayko sdal 5 litrov krovi dlya installyatsii." 16.07.2012 [Балакир, Анна. "Художник Тарас Полатайко сдал 5 литров крови для инсталляции." 16.07.2012] <https://gazeta.ua/ru/articles/culture/_ hudozhnik-taras-polatajko-sdal-5-litrov-krovi-dlya-installyacii/445931>.

Biedermann, Hans. Entsiklopediya simvolov. Transl. Val'kov V. et al. Moskva: Respublika, 1996 [Бидерманн Ганс. Энциклопедия символов. Пер. Вальков В. и др. Москва: Республика, 1996].

57 С. Алексиевич, Интервъю автора с самой собой о пропущенной истории и о том, почему Чернобыль ставит под сомнение нашу картину мира // Чернобыльская молитва. Хроника будущего, Время, Москва 2013, с. 32.

${ }^{8}$ О. Довгополова, Путешествия по слоям памяти/амнезии, 24.07.2019, бесед. Е. Буцикина, http://www.korydor.in.ua/ua/opinions/11917.html (02.04.2020). 
Bol'shoy tolkovyy slovar' russkogo yazyka. Ed. Kuznetsov, Sergey Aleksandrovich. Sankt-Peterburg: «Norint», 2006 [Большой толковый словарь русского языка. Ред. Кузнецов, Сергей Александрович. Санкт-Петербург: «Норинт», 2006].

Botanova, Katerina. "S chem rabotayet sovremennoye iskusstvo? Ukrainskiy kontekst." 15.03.2013 [Ботанова, Катерина. "С чем работает современное искусство? Украинский контекст." 15.03.2013] <http://eurocafe.by/ lecture/2013/08/21/s_chem_rabotaet_sovremennoe_iskusstvo_ukrainskii_ kontekst>.

Breus, Aleksey. "Chernobyl' - eto ne tol'ko 'chudovishche, porozhdennoye snom razuma', eto yeshche i grandioznoye proizvedeniye iskusstva!” Besed. Lobanovskaya, Anna [Бреус, Алексей. "Чернобыль - это не только "чудовище, порожденное сном разума', это еще и грандиозное произведение искусства!" Бесед. Лобановская, Анна] <http://pripyat.com/literatureand-art/khudozhnik-aleksei-breus-chernobyl-eto-ne-tolko-chudovishcheporozhdennoe-snom-ra>.

“Chernobyl'skaya katastrofa - bol' Ukrainy.” 18.01.2011 [“Чернобыльская катастрофа - боль Украины” 18.01.2011], <https://tsdea.archives.gov.ua/ exhibitions_ru/chern/index_ch.php?page=ch_history1 $>$.

Chudova, Anastasiya. Edvard Munk. Moskva: Izdatel'stvo AST, 2018 [Чудова, Анастасия. Эдвард Мунк. Москва: Издательство АСТ, 2018].

Cooper, Jean. Entsiklopediya simvolov. Transl. Komarov, I. V. Moskva: Zolotoy Vek, 1995 [Купер, Джин. Энциклопедия символов. Пер. Комаров, И. В. Москва: Золотой Век, 1995].

Domnikov, Sergey Dmitriyevich. Mat'-zemlya i Tsar'-gorod. Rossiya kak traditsionnoye obshchestvo. Moskva: Aletey·a, 2002 [Домников, Сергей Дмитриевич. Мать-земля и Царь-город. Россия как традиционное общество. Москва: Алетейа, 2002].

Doroshenko, Konstantin. "Konets sveta. Iskusstvo Chernobylya." 21.12.2012 [Дорошенко, Константин. "Конец света. Искусство Чернобыля.” 21.12.2012] < https:// artguide.com/posts/277-koniets-svieta-iskusstvo-chiernobylia-307>.

Dovgopolova, Oksana. "Puteshestviya po sloyam pamyati/amnezii." 24.07.2019. Besed. Butsikina, Yevgeniya [Довгополова, Оксана. "Путешествия по слоям памяти/амнезии.” 24.07.2019. Бесед. Буцикина, Евгения] <http://www. korydor.in.ua/ua/opinions/11917.html>.

Etkind, Aleksandr. Krivoye gore. Pamyat' o nepogrebennykh. Moskva: Novoye Literaturnoye Obozreniye, 2016 [Эткинд, Александр. Кривое горе. Память о непогребенных. Москва: Новое Литературное Обозрение, 2016].

Finkel'shteyn, Larisa. “Gobelen 'Chernobyl' - dar Belarusi OON.” [Финкельштейн, Лариса. “Гобелен 'Чернобыль' - дар Беларуси ООН.”] < http://www.un.org/ $\mathrm{ru} /$ events/chernobyl/gobelen.shtml>.

Foley, John. Entsiklopediya znakov i simvolov. Transl. Pomogaybo, Aleksandr. Moskva: Veche, 1997 [Фоли, Джон. Энциклопедия знаков и символов. Пер. Помогайбо, Александр. Москва: Вече, 1997].

Gavrilov, Dmitriy Anatol'yevich. Nordkheym. Kurs sravnitel'noy mifologii drevnikh germantsev i slavyan. Moskva: Sotsial'no-politicheskaya MYSL', 2006 [Гаврилов, Дмитрий Анатольевич. НордХейм. Курс сравнительной мифологии древних германцев и славян. Москва: Социально-политическая МЫСЛЬ, 2006]. 
"Humanistyka trzydzieści lat po Czarnobylu. Dyskusja panelowa.” Uczestnicy: Hundorowa, Tamara. Iwasiów, Inga. Majewski, Tomasz. Prowadzenie: Grzemska, Aleksandra. Po Czarnobylu. Miejsce katastrofy $w$ dyskursie współczesnej humanistyki. Eds. Boruszkowska, Iwona. Glinianowicz, Katarzyna. Grzemska, Aleksandra. Krupa, Paweł. Kraków: Wydawnictwo Uniwersytetu Jagiellońskiego, 2017. 359-377.

Hundorowa, Tamara. "Gatunek czarnobylski: wyparcie realnego i nuklearna sublimacja." Transl. Tomanek, Przemysław. Po Czarnobylu. Miejsce katastrofy $w$ dyskursie wspótczesnej humanistyki. Eds. Boruszkowska, Iwona. Glinianowicz, Katarzyna. Grzemska, Aleksandra. Krupa, Paweł. Kraków: Wydawnictwo Uniwersytetu Jagiellońskiego, 2017. 55-66.

Hundorowa, Tamara. "Post-Chernobyl': katastrofizm i nuklearnaya sublimatsiya." Russkaya antropologicheskaya shkola. Trudy 2012, № 11. 102-119 [Гундорова, Тамара. "Пост-Чернобыль: катастрофизм и нуклеарная сублимация." Русская антропологическая школа. Труды 2012, № 11. 102-119].

Hundorowa, Tamara. Pislyachornobyl's'ka biblioteka: Ukrayins'kyy literaturnyy postmodern . Kyyiv: Krytyka, 2005 [Гундорова, Тамара. Післячорнобильсъка бібліотека: Украӥнський літературний постмодерн. Київ: Критика, 2005].

Kopaliński Władysław. Stownik symboli. Warszawa: Oficyna wydawnicza RYTM, 2001.

Lyotard, Jean-François. "Otvet na vopros: chto takoye postmodern?" Transl. Garadzha, Aleksey. Ad Marginem'93. Moskva: Ad Marginem, 1994. 303-323 [Лиотар, Жан-Франсуа. “Ответ на вопрос: что такое постмодерн?” Пер. Гараджа, Алексей. Ad Marginem'93. Москва: Ad Marginem, 1994. 303-323].

Marder, Mikhail. "Filosofskaya antropologiya, sovremennyye media i filosofiya rasteniy.” Besed. Doronina, Anna. Bashkov, Vladimir. Breus, Andrey. Vysshaya shkola ekonomiki. 20.07.2018 [Мардер, Михаил. "Философская антропология, современные медиа и философия растений.” Бесед. Доронина, Анна. Башков, Владимир. Бреус, Андрей. Высшая школа экономики. 20.07.2018] <https://www.hse.ru/ma/philosophical/news/221806466.html>.

Men', Aleksandr Vladimirovich. Chitaya Apokalipsis. Moskva: Fond im. A. Menya, 2000 [Мень, Александр Владимирович. Читая Апокалипсис. Москва: Фонд им. А. Меня, 2000].

Plotnikova, Anna Arkad'yevna. "Polnyy-Pustoy." Slavyanskiye drevnosti. Etnolingvisticheskiy slovar'. Ed. Tolstoy, Nikita Il'ich. Vol. 4. Moskva: Institut slavyanovedeniya RAN - Mezhdunarodnyye otnosheniya, 2009. 145-147 [Плотникова, Анна Аркадьевна. “Полный-Пустой." Славянские древности. Этнолингвистический словарь. Ред. Толстой, Никита Ильич. Т. 4. Москва: Институт славяноведения РАН - Международные отношения, 2009. 145147].

Po Czarnobylu. Miejsce katastrofy $w$ dyskursie wspótczesnej humanistyki. Eds. Boruszkowska, Iwona. Glinianowicz, Katarzyna. Grzemska, Aleksandra. Krupa, Paweł. Kraków: Wydawnictwo Uniwersytetu Jagiellońskiego, 2017.

Szurik, Bartosz. "A-pop-kalipsa.” Znak 2013, no. 692. 122-127.

"Tolkovaniya na Otkr. 6:11" [Толкования на Откр. 6:11] <http://bible.optina.ru/ new:otkr:06:11>.

Tolstaya, Svetlana Mikhaylovna. "Kolybel'." Slavyanskiye drevnosti. Etnolingvisticheskiy slovar'. Ed. Tolstoy, Nikita Il'ich. Vol. 2. Moskva: Institut slavyano- 
vedeniya RAN - Mezhdunarodnyye otnosheniya, 1999. 559-562 [Толстая, Светлана Михайловна. “Колыбель.” Славянские древности. Этнолингвистический словарь. Ред. Толстой, Никита Ильич. Т. 2. Москва: Институт славяноведения РАН - Международные отношения, 1999. 559-562].

Toporov, Vladimir Nikolayevich. Mifologiya. Stat’i dlya mifologicheskikh entsiklopediy. Pref. Ivanov, Vyacheslav Vsevolodovich. Ed. Grigoryan, Armen Grachikovich. Vol. 1-2. Moskva: Yazyki slavyanskikh kul'tur, 2011, 2014 [Топоров, Владимир Николаевич. Мифология. Статьи для мифологических энциклопедий. Предисл. Иванов, Вячеслав Всеволодович. Ред.-сост. Григорян, Армен Грачикович. Т. 1-2. Москва: Языки славянских культур, 2011, 2014]. Ushakin, Sergey. "Nam etoy bol'yu dyshat"?: O travme, pamyati i soobshchestvakh." Travma: punkty. Eds. Ushakin, Sergey. Trubina, Yelena. Moskva: Novoye literaturnoye obozreniye, 2009. 5-41 [Ушакин, Сергей. “Нам этой болью дышать'?: О травме, памяти и сообществах.” Травма: пункты. Ред. Ушакин, Сергей. Трубина, Елена. Москва: Новое литературное обозрение, 2009. 5-41].

Valentsova, Marina Mikhaylovna. Uzeneva, Yelena Semenovna. "Nachalo-Konets." Slavyanskiye drevnosti. Etnolingvisticheskiy slovar'. Ed. Tolstoy, Nikita Il'ich. Vol. 3. Moskva: Institut slavyanovedeniya RAN - Mezhdunarodnyye otnosheniya, 2004. 372-376 [Валенцова, Марина Михайловна. Узенёва, Елена Семёновна. "Начало-Конец." Славянские древности. Этнолингвистический словарь. Ред. Толстой, Никита Ильич. Т. 3. Москва: Институт славяноведения РАН - Международные отношения, 2004. 372-376].

Virilio, Paul. Aleksiyevich, Svetlana. [Beseda]. "Radioaktivnyy ogon'. Pochemu opyt Chernobylya stavit pod somneniye nashu kartinu mira." Lettre International 2003, no. 1 (60). 11-15 [Вирилио, Поль. Алексиевич, Светлана. [Беседа]. "Радиоактивный огонь. Почему опыт Чернобыля ставит под сомнение нашу картину мира."] <http://alexievich.info/wp-content/uploads/articlesDialog. pdf $>$.

Zabużko, Oksana. "Planeta Piołun - Dowżenko - Tarkowski - von Trier albo dyskurs nowej grozy." Transl. Kotyńska, Katarzyna. Po Czarnobylu. Miejsce katastrofy $w$ dyskursie wspótczesnej humanistyki. Eds. Boruszkowska, Iwona. Glinianowicz, Katarzyna. Grzemska, Aleksandra. Krupa, Paweł. Kraków: Wydawnictwo Uniwersytetu Jagiellońskiego, 2017. 36-51.

Zhuk, Valeriy Ivanovich. Zhivopis' Belarusi na rubezhe vekov: poteri i obreteniya, Minsk: Byelaruskaya navuka, 2013 [Жук, Валерий Иванович. Живопись Беларуси на рубеже веков: потери и обретения. Минск: Беларуская навука, 2013].

“Zvezda tral'frealizma: zhivyye tsvety i zhivyye kartiny.” 17.09.2008 [“Звезда тральфреализма: живые цветы и живые картины.” 17.09.2008] < http://gloss.ua/ event/Zvezda_tralfrealizma_zhivye_cvety_i_zhivye_kartiny>. 